Abstract 200 Table 2 A review of autonomic dysfunctions in the casaes.

\begin{tabular}{|c|c|c|c|c|c|c|c|c|c|c|}
\hline Cose No & $\operatorname{Cose} 1$ & $\operatorname{cose} 2$ & Potient 1 & Potient 2 & Patient 3 & Potient 4 & Patient 5 & Patient 6 & Potient 7 & Potient 8 \\
\hline $\begin{array}{l}\text { SLE disease } \\
\text { duration st onset } \\
\text { of pan- } \\
\text { dysautonomin }\end{array}$ & $5 y z$ & $\begin{array}{l}\text { pan- } \\
\text { dyazutonom } \\
\text { ia as initial } \\
\text { spmemtom }\end{array}$ & $\begin{array}{l}\text { pan- } \\
\text { Cysautocom } \\
\text { ia as initial } \\
\text { opptom }\end{array}$ & $\begin{array}{l}\text { pan- } \\
\text { dyautonom } \\
\text { ia as initial } \\
\text { gypmtom }\end{array}$ & $4 y=$ & $\begin{array}{l}\text { pan- } \\
\text { oysautonom } \\
\text { ia as initóal } \\
\text { sypmtom }\end{array}$ & $\begin{array}{l}\text { pan- } \\
\text { oyautonom } \\
\text { la as initial } \\
\text { sypmtom }\end{array}$ & $\begin{array}{l}\text { pan- } \\
\text { dyautonom } \\
\text { ia as initial } \\
\text { opmtom }\end{array}$ & $2 \gamma$ & $\begin{array}{l}\text { pan- } \\
\text { dyaautonom } \\
\text { ia as initial } \\
\text { sypmtom }\end{array}$ \\
\hline Author and year & $\begin{array}{l}\text { Presenting } \\
2016\end{array}$ & $\begin{array}{l}\text { Presenting. } \\
2016\end{array}$ & $\begin{array}{l}\text { Dale et al, } \\
2012\end{array}$ & $\begin{array}{l}\text { Wong et al, } \\
2011\end{array}$ & $\begin{array}{l}\text { Yulawa } \\
\text { a. } 20005\end{array}$ & $\begin{array}{l}\text { Law et al. } \\
2006\end{array}$ & $\begin{array}{l}\text { lodo et al. } \\
1992\end{array}$ & $\begin{array}{l}\text { Otokida et } \\
\text { at } 1990\end{array}$ & $\begin{array}{l}\text { Aervda et al. } \\
1959\end{array}$ & $\begin{array}{l}\text { Hoyle et at } \\
1985\end{array}$ \\
\hline Sympothetic & $\begin{array}{l}\text { OHtayncope } \\
\text { tantidropis }\end{array}$ & $\begin{array}{l}\text { OHtayncope } \\
\text { tantidrosis }\end{array}$ & $\mathrm{OH}$ & $\begin{array}{l}\text { OH+anhidro } \\
\text { is }\end{array}$ & $\begin{array}{l}\text { OH+Syncope } \\
\text { tanhidrosis }\end{array}$ & $\mathrm{OH}$ & $\begin{array}{l}\mathrm{OH}+\text { anhicio } \\
\text { is }\end{array}$ & $\begin{array}{l}\text { OH+Syncope } \\
\text { tanhidrosis }\end{array}$ & $\mathrm{NM}$ & $\mathrm{OH}$ \\
\hline Parsoympathetic & $\begin{array}{l}\text { Dry MBE } \\
\text { +popil } \\
\text { ebroormityt }\end{array}$ & Dry MBE & $\begin{array}{l}\text { Pupl } \\
\text { abnormityt } \\
\text { dyaunia }\end{array}$ & Dyauria & $\begin{array}{l}\text { Dry MBE } \\
\text { +pupil } \\
\text { abnormity+ }\end{array}$ & Dry MSE & $\begin{array}{l}\text { Dry MBE } \\
\text { tpupil } \\
\text { aboormityt }\end{array}$ & $\begin{array}{l}\text { Pupl } \\
\text { abnormityt } \\
\text { dyauria }\end{array}$ & $\begin{array}{l}\text { Pupil } \\
\text { aboormity+ } \\
\text { dyauria }\end{array}$ & $\begin{array}{l}\text { Dry MEE } \\
\text { +pupil } \\
\text { abnormity+ }\end{array}$ \\
\hline $\begin{array}{l}\text { G1 tract } \\
\text { involvement }\end{array}$ & $\begin{array}{l}\text { dysuria } \\
\text { Psedo- } \\
\text { obatruction }\end{array}$ & $\begin{array}{l}\text { Predo- } \\
\text { obstruction }\end{array}$ & $\begin{array}{l}\text { Predo- } \\
\text { obstruction }\end{array}$ & $\begin{array}{l}\text { Not } \\
\text { mentioned }\end{array}$ & $\begin{array}{l}\text { Spauria } \\
\text { Pesdo- } \\
\text { obstruction }\end{array}$ & $\begin{array}{l}\text { Abdominal } \\
\text { pain }\end{array}$ & $\begin{array}{l}\text { bysuria } \\
\text { Predo- } \\
\text { obatruction }\end{array}$ & Constipation & $\begin{array}{l}\text { Predo- } \\
\text { obstruction }\end{array}$ & $\begin{array}{l}\text { dyauria } \\
\text { Absiominal } \\
\text { pain }\end{array}$ \\
\hline Cordiovasoular & Abnormal & Abnormal & Abrormal & Abnormal & Abrormal & Abnormal & Abnormal & Abnormal & Abnomal & Aboormal \\
\hline AChR antibody & $\begin{array}{l}\text { Positive in } \\
\text { CSF }\end{array}$ & $\begin{array}{l}\text { Positive in } \\
\text { CSF }\end{array}$ & $\begin{array}{l}\text { Positive in } \\
\text { gervm }\end{array}$ & NM & NM & NM & NM & NM & NM & NM \\
\hline
\end{tabular}

OH: orthostatic hypotension; M\&E: mouth and eye; NM: not mentioned/measured; GI: gastro-intestinal.

Abstract 200 Table 3 A review of the treatments in reported cases.

\begin{tabular}{|c|c|c|c|c|c|c|c|c|c|c|}
\hline Cose No & Case 1 & Cose 2 & Patient 1 & Patient 2 & Patient 3 & Patient 4 & Patient 5 & Patient 6 & Patient 7 & Potient 8 \\
\hline $\begin{array}{l}\text { Author and } \\
\text { year }\end{array}$ & $\begin{array}{l}\text { Presenting. } \\
2016\end{array}$ & $\begin{array}{l}\text { Presenting. } \\
2016\end{array}$ & $\begin{array}{l}\text { Dale et al. } \\
2012\end{array}$ & $\begin{array}{l}\text { Wong et al. } \\
2011\end{array}$ & $\begin{array}{l}\text { Yulawa et al. } \\
2008\end{array}$ & $\begin{array}{l}\text { Law et al. } \\
2006\end{array}$ & $\begin{array}{l}\text { Jodo et al. } \\
1992\end{array}$ & $\begin{array}{l}\text { Otokida et } \\
\text { a. } 1990\end{array}$ & $\begin{array}{l}\text { Arruda et al. } \\
1959\end{array}$ & $\begin{array}{l}\text { Hoyle et al } \\
1985\end{array}$ \\
\hline Corticosteroid & $\begin{array}{l}\text { MP } 1 \mathrm{~g} \times 3 d \\
\vec{P} 1 \mathrm{mg} / \mathrm{g} / \mathrm{d}\end{array}$ & $P 1 \mathrm{mg} / \mathrm{kg} / \mathrm{d}$ & $P 1 \mathrm{mg} / \mathrm{kg} / \mathrm{d}$ & $P 1 \mathrm{mg} / \mathrm{kg} / \mathrm{d}$ & $\begin{array}{l}M P 1 \mathrm{~g} \times 3 \mathrm{~d} \\
\text { twice- } \\
P 1 \mathrm{mg} / \mathrm{kg} / \mathrm{d}\end{array}$ & $\begin{array}{l}M P 0.5 \mathrm{~g} \times 3 \mathrm{~d} \\
\overrightarrow{P 1 \mathrm{mg} / \mathrm{kg} / \mathrm{d}}\end{array}$ & $\begin{array}{l}M P 1 \mathrm{~g} \times 3 \mathrm{~d} \\
\times 3 \text { times } \rightarrow \\
P 1 \mathrm{mg} / \mathrm{gg} / \mathrm{d}\end{array}$ & $\begin{array}{l}P \\
0.8 \mathrm{ng} / \mathrm{g} / \mathrm{d}\end{array}$ & Psomg qd & $\begin{array}{l}\text { Dex in (dose } \\
\text { unknown) }\end{array}$ \\
\hline $\begin{array}{l}\text { Immunosuppr } \\
\text { esants }\end{array}$ & $\begin{array}{l}\text { Tacrolimus } \\
2 m g \text { bid po }\end{array}$ & $\begin{array}{l}\text { Cre } 400 \mathrm{mg} \\
\text { ivew }\end{array}$ & azd $75 \mathrm{mg}$ & $\begin{array}{l}\text { CVC 750mg } \\
\text { ivd6 }\end{array}$ & $\begin{array}{l}\text { Cre } 750 \mathrm{mg} \\
\text { iv d55, } 883\end{array}$ & $A Z A+H C Q$ & AZA & No use & No use & No use \\
\hline MG & $20 g \varphi d \times 5 d$ & No use & No use & No use & No use & No use & No use & No use & No vse & No wse \\
\hline $\begin{array}{l}\text { Plasma } \\
\text { exchange }\end{array}$ & No use & $\begin{array}{l}016,021 \\
024,029\end{array}$ & No use & No use & $\begin{array}{l}D 19, d 21, d 31 \\
d 34\end{array}$ & No use & No use & No use & No use & No use \\
\hline Other meds & $\begin{array}{l}\text { Midodrine } \\
\text { Pridostigmi } \\
\text { ne } \\
\text { fludrocortieo } \\
\text { ne }\end{array}$ & $\begin{array}{l}\text { Midodrine, } \\
\text { fludrocortion } \\
\text { e }\end{array}$ & $\begin{array}{l}\text { Botulinium A } \\
\text { toxin }\end{array}$ & No use & No use & No use & No use & Suprifen HCL & $\begin{array}{l}\text { Pridostigni } \\
\text { ne }\end{array}$ & No use \\
\hline $\begin{array}{l}\text { Curstive } \\
\text { effective } \\
\text { Length of stay }\end{array}$ & $\begin{array}{l}\text { Sow } \\
\text { recovery } \\
104 \text { days }\end{array}$ & $\begin{array}{l}\text { Rapid } \\
\text { recovery } \\
36 \text { days }\end{array}$ & $\begin{array}{l}\text { Slow } \\
\text { recovery } \\
\text { NM }\end{array}$ & $\begin{array}{l}\text { Slow } \\
\text { recovery } \\
30 \text { days }\end{array}$ & $\begin{array}{l}\text { Rapid } \\
\text { recovery } \\
101 \text { days }\end{array}$ & $\begin{array}{l}\text { Rapid } \\
\text { recovery } \\
\text { NM }\end{array}$ & $\begin{array}{l}\text { Rapid } \\
\text { recovery. } \\
260 \text { days }\end{array}$ & $\begin{array}{l}\text { Sow } \\
\text { recovery } \\
\text { NM }\end{array}$ & $\begin{array}{l}\text { Slow partial } \\
\text { recovery. } \\
\text { NM }\end{array}$ & $\begin{array}{l}\text { Rapid ful } \\
\text { recovery } \\
53 \text { days }\end{array}$ \\
\hline
\end{tabular}

MP: methylprednisolone, P: prednisolone, NM: Not mentioned;

\section{PROCALCITONIN AND EOSINOPENIA AS POTENTIAL BIOMARKERS OF INFECTION IN CRITICALLY ILL PATIENTS WITH SYSTEMIC LUPUS ERYTHEMATOSUS}

1J Aponte, ${ }^{2} \mathrm{~J}$ Carrizosa, ${ }^{3} \mathrm{~A}$ Sanchez, ${ }^{1} \mathrm{~A}$ Cartagena, ${ }^{4} \mathrm{MT}$ Ospina, ${ }^{5} \mathrm{C}$ Gamboa, ${ }^{6} \mathrm{R}$ Cervera. ${ }^{1}$ Hospital Universitario de La Samaritana - Universidad de la Sabana, Medicina Interna, Bogota, Colombia; ${ }^{2}$ Universidad del Rosario, Cuidado critico, Bogota, Colombia; ${ }^{3}$ Hospital Universitario de La Samaritana, Medicina Interna - Cuidado Critico, Bogota, Colombia; ${ }^{4}$ Hospital Universitario de La Samaritana, Cuidado critico, Bogota, Colombia; ${ }^{5}$ Universidad de La Sabana, Pregrado Medicina, Bogota, Colombia; ${ }^{6}$ Senior y Jefe del Servicio de Enfermedades Autoinmunes del Hospital Clínic de Barcelona, Enfermedades Autoinmunes, Barcelona, Spain

\subsection{6/lupus-2017-000215.201}

Background and aims Introduction: systemic lupus erythematosus (SLE) is one of most prevalent autoimmune diseases in critical care in the last years and is associated with many complications, the infections are an important cause of mortality which makes necessary a rapid and precise diagnostic approach.
Methods A retrospective study was conducted, 56 patients with SLE were admitted to the intensive care unit (ICU) at a University Hospital in Bogotá, Colombia, between 2008 and 2016. The average age was 40.7 years old ( $\mathrm{SD} \pm 17.7 \mathrm{y} / \mathrm{o}$ ), female sex was predominant ( $71 \%$ vs $29 \%)$. Correlation between procalcitonin and eosinopenia in patients with positive cultures in bivariate analysis was performed to identify if there was a possible association to include those variables in a logistic regression model to establish an association with positive cultures.

Results two variables consistently associated with positive cultures in the logistic regression model, which had adequate prediction parameters: procalcitonin $\geq 2.0 \mathrm{ng} / \mathrm{ml}$ (OR: 6.076; $95 \%$ CI 1.75 to $20.79, \mathrm{p}=0.004)$, absolute count of eosinophil <30 cells $/ \mathrm{mm}^{3}$ (OR: 3.45; 95\% CI 1.01 to 11.7 , $\mathrm{p}=0.047$ ).

Conclusion These variables could guide clinicians in early identification of patients with SLE and infectious diseases as a cause of critical illness, leading to early antibiotic therapy to 
improve survival rates. These results should be evaluated prospectively in future studies to find the prediction power in the differentiation of flare and sepsis in this group of patients.

\section{THE ROLE OR NEUTROPHIL-LYMPHOCYTE RATIO(NLR), AND OTHER BIOMARKERS (C - REACTIVE PROTEIN CRP, COUNT OF MONOCITES AND LYMPHOCITES) DIFFERENTIATING LUPIC ACTIVITY (FLARE) FROM INFECTION}

1J Aponte, ${ }^{2} \mathrm{~J}$ Carrizosa, ${ }^{3} \mathrm{~A}$ Sanchez, ${ }^{4} \mathrm{M}$ Ospina, ${ }^{1} \mathrm{~A}$ Cartagena, ${ }^{1} \mathrm{C}$ Zapata*, ${ }^{5} \mathrm{R}$ Cervera. ${ }^{1}$ Hospital Universitario de la Samaritana - Universidad de la Sabana, Medicina Interna, Bogota, Colombia; ${ }^{2}$ Universidad del Rosario, Especialista en Cuidado Critico, Bogota, Colombia; ${ }^{3}$ Hospital Universitario de la Samaritana, Cuidado intensivo - Medicina interna, Bogota, Colombia; ${ }^{4}$ Hospital Universitario de la Samaritana, Cuidado intensivo, Bogota, Colombia; ${ }^{5}$ Hospital Clínic de Barcelona, Médico Consultor Senior y Jefe del Servicio de Enfermedades Autoinmunes del Hospital Clínic de Barcelona, Barcelona, Spain

\subsection{6/lupus-2017-000215.202}

Background and aims Systemic lupus erythematosus (SLE) is one of the most prevalent connective tissue diseases, it is commonly associated with an infection being so difficult to differentiate if the systemic inflammatory response is secondary to a bacterial infection, or to the underlying autoimmune activity (FLARE). The aim of this study was to determine the utility of $\mathrm{C}$ reactive protein (CRP), neutrophil-lymphocyte ratio (NLR), count of monocites, and lymphocites in patients with positive cultures and flare.

Methods A retrospective study was conducted, 58 patients with SLE were admitted to the intensive care unit (ICU) at a University Hospital in Bogotá, Colombia, between 2008 and 2017. Bivariate analysis was performed to identify if there was a possible association with positive cultures in patients with (flare)

Results In patients with lupic activity (SLEDAI:8-12) NRL was consistently associated with flare, NRL $>10$ (OR: 17; 95\% CI 2.13 to $136.8, \mathrm{p}=0.007)$, count of lymphocites $<500$ cells/ $\mathrm{mm}^{3}$ was associated with lupic activity (OR: 6.33; 95\% CI 1.30 to $30.7, \mathrm{p}=0.022$ ), in severe lupic activiy de CRP did not show association; one variable consistently associated with positive cultures in the logistic regression model with adequiate prediction parameters: absolute count of monocite $>400 \mathrm{cell} / \mathrm{mm} 3$ (OR: 3.51 ; 95\% CI 1.13 to $10.88, \mathrm{p}=0.029$ ), the others variables NRL, CRP showed no association with positive cultures.

Conclusions The (NRL) $>10$ Could help to differentiate LES activity from infection, leading to early antibiotic therapy, or immunotherapy to improve survival rates. These results should be evaluated prospectively in future studies.

\section{SLE Organ manifestations: clinical and pathogenesis}

\section{EYE MANIFESTATIONS OF LUPUS}

E Abd ElLatif. Alexandria, Egypt

\subsection{6/lupus-2017-000215.203}

Background and aims The body is one unit and the ultimate care of a patient with a multisystem disease such as lupus requires the integrated care of several specialists. Systemic lupus has some potentially blinding ocular complications such as lupus retinopathy. Early detection of these complications by the ophthalmologist can help salvage vision of the patient. Moreover, some cases present first to the ophthalmologist, so an ophthalmologist trained in detecting the ocular manifestations of multisystem diseases can refer the patient promptly to the rheumatologist and help minimise the disease-associated morbidity. The aim of this study was to describe the ocular manifestations of lupus in patients who presented to the main university hospital in Alexandria from July 2014 to March 2016.

Methods A prospective study was conducted and included 128 patients with lupus. A thorough ophthalmic examination was conducted by the author using the slitlamp biomicroscope and a fundus lens

Results Out of the 128 patients, 61 patients had lupus retinopathy at time of presentation or developed it de novo during the period of the study. Thirty two patients had lupus keratopathy. And eighty one patients had dry eye of various degrees of severity, 3 of them culminated into potentially sight threatening corneal ulcers. Communication with the treating rheumatologists was done and an overall $81 \%$ improvement in ocular lupus patients was achieved by the end of the study. One patient lost one eye due to late presentation

Conclusions Lupus is a potentially blinding disease requiring full cooperation between the ophthalmologist and the rheumatologist.

\section{SINGLE CENTRECENTER EXPERIENCE WITH 150 SYSTEMIC LUPUS ERYTHEMATOSUS PATIENTS}

S Tekeoglu, D Temiz Karadag, 0 Ozdemir Isik, A Yazici, A Cefle*. Kocaeli University, Internal Medicine- Rheumatology, Kocaeli, Turkey

\subsection{6/lupus-2017-000215.204}

Background and aims Systemic lupus erythematosus (SLE) is an autoimmune disease with diverse clinical manifestations. Here, we present 150 patients with SLE attending our clinic between January and November 2016.

Methods Demographics, clinics, laboratory findings, Systemic Lupus Erythematous Disease Activity Index (SLEDAI), Systemic Lupus International Clinics (SLICC)/American College of Rheumatology (ACR) damage index scores and treatments were analysed. Diagnosis was confirmed with 1997 ACR or 2012 SLICC classifications. Chi-squared or Fisher's exact tests were used for statistical analysis.

Results General characteristics are presented in Table 1. Clinics are presented in Table 2. Treatments patients ever received are presented in Table 3.

Conclusions SLICC damage was positive in patients receiving pulse steroids (57\%), cyclophosphamide (51\%), rituximab (73\%). In long term, 3 (2\%) patients had pulmonary

Abstract 204 Table 1 General characteristics

\begin{tabular}{ll}
\hline Age (years) & $46 \pm 12.8$ \\
\hline Disease duration (months) & $121.3 \pm 92.4$ (min-max:6-132) \\
Gender (Female/Male) & $139(92.7 \%) / 11(7.3 \%)$ \\
SLEDAI & min-max:0-30, median:1.5 \\
SLICC/ACR damage index & min-max:0-5, median:0 \\
\hline
\end{tabular}

